\title{
RESEÑA
}

\section{Les ordres de sagesse du rite français. Au coeur de la franc-maçonnerie libérale, des Lumières au XXIe siècle de Cécile Révauger y Ludovic Marcos. Paris: Dervy, 2015. 280 páginas. ISBN-10: 1024201155. ISBN- 13: 978-1024201154.}

Reseñado por Yván Pozuelo Andrés

Doctor en Historia, Universidad de Oviedo, 2004. Profesor del IES Universidad Laboral de Gijón, España. Editor de la REHMLAC+. Miembro del Centro de Estudios Históricos de la Masonería Española de la Universidad de Zaragoza, España. Correo electrónico: yvan@telecable.es

DOI: http://dx.doi.org/10.15517/rehmlac.v8i1.24289

Fecha de recibido: 12 enero de 2016 - Fecha de aceptación: 1 febrero de 2016

El título, subtítulo y autores son el aliage perfecto para interesarse por un tema, que parece con los debidos prejuicios, una inquietud interna a una rama específica de la masonería como la representada por la obediencia del Gran Oriente de Francia y en concreto de un Rito, el francés, en sus grados superiores. Las credenciales historicistas de los autores abren las puertas grandes al interés histórico : ¿cómo se organiza y reorganiza una sociabilidad o parte de la misma frente a momentos históricos que interfieren negativamente en su vida? La edición del libro que recibió el apoyo del Gran Capítulo General del Rito Francés del Gran Oriente de Francia garantizó la máxima calidad de la tirada que cuenta con unas ilustraciones de gran belleza y detalle, pruebas del tiempo pasado y de su evolución hasta nuestros días, pertenecientes a los tesoros iconográficos conservados en el museo de la Masonería de París, rue Cadet. El libro dividido en siete capítulos recorre cronológicamente la historia de los altos grados del Rito francés, incluyendo en los dedicados a la segunda mitad del siglo XX y principios del XXI unos testimonios de varios de sus protagonistas.

\section{La Historia de los altos grados}

Si principalmente es un libro dirigido hacia un público masónico afín al sentir del GODF, desde una perspectiva interna, se abre al interés histórico por presentar las vicisitudes históricas de una práctica nacida en el siglo XVIII, luego abandonada y finalmente recuperada en el siglo XX. Los autores se adentran profusamente en explicar lo qué son estos altos grados, sus orígenes y las razones de su abandono y recuperación. Su disposición se fue construyendo con dificultad durante varios años a partir del fallecimiento 
del que fuera Gran Maestre desde 1743 a 1771, Louis de Bourbon-Condé, Conde de Clermont. Interesante resulta descubrir las opiniones de los masones según fueron presentadas las propuestas del ritual pretendido donde aflora la realidad de sus preocupaciones y su nivel de crítica sobre lo propuesto, incluso rechazando propuestas por considerarlas como antimasónicas. Roêttiers de Montaleau fue el más activo en cuanto a propuestas de grados. Tras alguna oposición, el Gran Capítulo general, con fuerte sello parisino, se pone en marcha a finales de 1784. El Gran Oriente de Francia, pasadas numerosas reticencias, lo integraría en 1788. Paciencia, reflexión y debate rigieron la armonización de este singular organismo. La Revolución Francesa frenó su desarrollo hasta su inmovilización, retomándolo al final de la misma y sobre todo después, a principios del siglo XIX. En esos principios se quedó, pues, se esfumó, reapareciendo jen 1963! A partir de entonces, la labor realizada en la época del XVIII se impuso en el quehacer del Rito francés en el Gran Oriente de Francés. La modernidad trajo la tradición.

La parte dedicada a la resurrección de estos altos grados en la segunda parte del XX es sumamente interesante porque los autores relatan su proceso de forma muy detallada en base a los testimonios de sus protagonistas. Este nivel de detalle suele faltar, obviamente, a la hora de describir procesos similares en siglos anteriores de ahí que nos pueda ayudar esta descripción para al menos intuirlos : lentos, divididos, críticos, reflexivos, personalistas, discutidos y de amplias y diversas influencias.

\section{Los testimonios}

Con más de dos decenas de entrevistas a protagonistas de la resurrección de los altos grados del Rito Francés se recorre el camino masónico individual de los mismos en relación con su desarrollo. En ellas, destacan los numerosos debates que provocó este rescate histórico en el seno de una obediencia que ya no era exactamente la misma que en sus orígenes. El tema más polémico y de mayor de reflexión fue la laicización de esos rituales para ponerlos acordes con el espíritu laico de la obediencia de la segundad mitad del siglo XX. A través de ellos, quedó claro que no existió una única corriente laica en el seno de la obediencia pues hubo bastantes reticencias e incluso resistencia para que no se actualizasen y eliminasen el deísmo de este rito. Esos debates tienen un interés histórico porque nos acercan a la comprensión ideológica de una época, de una generación o de una organización. En resumidas cuentas, estos protagonistas actuales de las cuatro órdenes que componen los altos grados del Rito Francés tuvieron que decidir sobre el peso ideológico de las palabras. Como decía Guy de Maupassant las palabras tienen un alma, y en torno a él los masones descritos en esta obra reflexionaron. Trasladando este debate al mundo ajeno a la masonería podríamos interrogarnos si cuando un ateo o un partidario del laicismo pronuncia la palabra "Dios", "Virgen" o cualquier expresión tradicional como "Dios mío" 
¿estaría traicionado su ateísmo o su laicismo? O se entiende de por sí que ¿esas palabras tan sólo cambiaron de estado?

\section{Conclusiones}

Es un libro muy del Gran Oriente de Francia, de su personalidad masónica, cuyas páginas históricas recorridas aquí a través de la historia de los Altos Grados de un Rito, Francés, muestra la diversidad de los siglos, pues, creado en el XVIII, desaparece en el XIX, y renace en el XX. ¿Qué queda de los orígenes dos siglos en adelante? Fue la pregunta crucial en torno a la cual los masones franceses lograron rescatar los Altos Grados del Rito Francés. En definitiva, otro exquisito trabajo de Cécile Révauger y de Ludovic Marcos. 